\title{
Seed and leaf-spray inoculation of PGPR in brachiarias (Urochloa spp.) as an economic and environmental opportunity to improve plant growth, forage yield and nutrient status
}

\author{
Mariangela Hungria $(\mathbb{D})$ Artur Berbel Lirio \\ Rondina $(\mathbb{D} \cdot$ Amanda Letícia Pit Nunes $\mathbb{D} \cdot$ Ricardo \\ Silva Araujo (D) Marco Antonio Nogueira \\ Received: 27 January 2021 / Accepted: 3 March 2021 / Published online: 11 March 2021 \\ (C) The Author(s) 2021, corrected publication 2021
}

\begin{abstract}
Purpose Brazil has 180 Mha of pastures, 86 Mha occupied with Urochloa spp. (syn. Brachiaria), and $70 \%$ in some level of degradation. Inoculation with plantgrowth-promoting bacteria (PGPR) may represent an economic and environmental feasible strategy to improve pasture production.
\end{abstract}

Responsible Editor: Richard J. Simpson.

M. Hungria $\cdot$ A. B. L. Rondina $\cdot$ M. A. Nogueira

Soil Biotechnology Laboratory, Embrapa Soja, C.P. 231,

Londrina, PR 86001-970, Brazil

\author{
A. B. L. Rondina \\ e-mail: arturrondina@hotmail.com \\ M. A. Nogueira \\ e-mail: marco.nogueira@embrapa.br
}

M. Hungria $(\bowtie) \cdot$ A. B. L. Rondina $\cdot$ M. A. Nogueira Conselho Nacional de Desenvolvimento Científico e Tecnológico, SHIS QI 1 Conjunto B, Blocos A, B, C e D, Lago Sul, Brasília, Distrito Federal 71605-001, Brazil

e-mail: mariangela.hungria@embrapa.br

e-mail: biotecnologia.solo@ hotmail.com

\section{A. L. P. Nunes - R. S. Araujo}

Total Biotecnologia Indústria e Comércio S/A, Biotrop, Rua Emílio Romani, 1190, CIC, 81460-020, Curitiba, PR, Brazil

\author{
A. L. P. Nunes \\ e-mail: amanda.nunes@biotrop.com.br \\ R. S. Araujo \\ e-mail: ricardo.araujo@biotrop.com.br
}

Methods Two greenhouse and seven field trials were performed to verify the effects of seed inoculation at sowing or leaf-spray inoculation in established pastures of Urochloa with elite strains of Azospirillum brasilense and Pseudomonas fluorescens. All plants received nutrients including $40 \mathrm{~kg} \mathrm{ha}^{-1}$ of $\mathrm{N}$ at sowing, and half of the treatments a supply of $40 \mathrm{~kg} \mathrm{ha}^{-1}$ of $\mathrm{N} 30$ days after emergence.

Results A. brasilense increased shoot biomass by an average of $16.8 \%$ with both seed and leaf-spray inoculation, whereas $P$. fluorescens increased by 15.2 and $14.2 \%$, respectively, always higher with the extra supply of N. Seed and leaf-spray inoculation with $A$. brasilense increased $\mathrm{N}$ content by an average of 11.7 and $20.7 \%$, and $\mathrm{K}$ by 9.9 and $11.3 \%$, respectively; for $P$. fluorescens average increases were of 33.3 and $36.6 \%$ for $\mathrm{P}$, and of 10.6 and $13.6 \%$ for K, respectively. Benefits were mainly attributed to improvements in root architecture by the synthesis of phytohormones. Biological nitrogen fixation in A. brasilense, $\mathrm{P}$ acquisition (solubilization of phosphates and siderophores synthesis) and ACCdeaminase in $P$. fluorescens also contributed to plant growth and nutrient status.

Conclusion Inoculation with elite PGPR strains translated into more fodder and improved nutritional value of feed for livestock, representing a promising and environmentally-friendly strategy for tropical pastures.

Keywords Azospirillum brasilense P Pseudomonas fluorescens - Root morphological traits · Nutrient uptake . Plant-growth-promoting bacteria 


\section{Introduction}

The most recent projections of the United Nations predict that the world population will reach 8.5 billion by 2030, and 9.7 billion by 2050 (United Nations 2019), bringing along the aggravation of food and energy shortage, and limitation of drinking water. The supply of animal protein is expected to be critical, and to achieve the increasing demand it would be necessary to occupy more land with crops to be transformed into feeds, or to clear more land to grow pastures for livestock. However, increasing land occupation with pastures presses the land use planetary boundary (Steffen et al. 2015), which is already at risk.

The Brazilian cattle herd was estimated as the second largest worldwide, with about 244 million head in 2020 (USDA 2020), fed predominantly by free grazing on pastures (probably more than 95\%), the most economical and practical way to provide food for herds (Jank et al. 2014). Extensive livestock has occupied large pasture areas in the country, with $21.2 \%$ of the territory, whereas $7.8 \%$ is used for grain production (Embrapa 2018). However, live weight gains and pasture carrying capacity depend on the quality and yield potential of the pastures (Santos et al. 2004).

Nowadays, there are about 180 million hectares (Mha) of land occupied by pastures in Brazil, with a total 120 Mha of cultivated pastures, 86 Mha of which with species of Urochloa (syn. Brachiaria). However, about $70 \%$ of the areas are at some level of degradation (Zimmer et al. 2012; Dias-Filho 2014; Unipasto, unpublished data, personal communication), resulting in poor quality of forage and, consequently, unfavorable conditions for livestock production and performance in terms of protein production. The increasing demand on animal protein to sustain the growth of the world's population requires that either more land is cleared for pastures, contributing to threaten the fragile planetary boundaries (Steffen et al. 2015), or that other beneficial approaches are employed to improve the quality of the existing pasturelands.

One such approach is the utilization of inoculants composed of plant-growth-promoting bacteria (PGPB), which comprise a group of beneficial soil bacteria that associate with plants, contributing to the overall fitness of the crops, improving root development, water and nutrient uptake, and tolerance to biotic and abiotic stresses (e.g. Hungria and Mendes 2015; Souza et al. 2015; Goswami et al. 2016; Fukami et al. 2018b; Santos et al. 2019). Bacterial species such as Azospirillum brasilense, Gluconacetobacter diazotrophicus, Bacillus subtilis, and Pseudomonas fluorescens, among others, have been shown to act as PGPB in association with an array of crops (Bashan et al. 2014); however, the great majority of the studies have been performed with grain crops, with few results on pastures.

A. brasilense strains CNPSo 2083 (=Ab-V5), and CNPSo 2084 (=Ab-V6) have been selected in Brazil initially for the maize (Zea mays L.) and wheat (Triticum aestivum L.) crops (Hungria et al. 2010), and in less than a decade the inoculant market of these two strains has grown exponentially, reaching 10.5 million doses in the 2019/20 (Santos et al. 2019, 2021). More recently, both strains have been successfully employed as seed inoculants in the establishment of pastures of two species of brachiaria, Urochloa brizantha and Urochloa ruziziensis, resulting in $15 \%$ and $25 \%$ increases in forage biomass production and nitrogen content, respectively (Hungria et al. 2016). In addition to the impressive increases in shoot biomass and protein production, the environmental impact should be highlighted, as inoculation with both strains implicated in $\mathrm{C}$ sequestration estimated at $0.309 \mathrm{Mg} \mathrm{ha}^{-1}$ per cut, representing plants growing for an average of three months, and equivalence to an additional application of $40 \mathrm{~kg} \mathrm{ha}^{-1}$ of N (Hungria et al. 2016).

Further studies confirmed the benefits of seed inoculation of these two A. brasilense strains in genotypes of $U$. ruziziensis and $U$. brizantha (Leite et al. 2019b; Duarte et al. 2020), Mavuno grass (Urochloa ruziziensis $\times U$. brizantha cv. Marandu $\times U$. brizantha apomictic) (Sá et al. 2019a), and Megathyrsus maximus (Jacq.) B.K.Simon \& Jacobs (syn. Panicum maximum) genotypes Zuri Guinea (Sá et al. 2019b) and Mombassa (Leite et al. 2019a). However, the great majority of the pastures in Brazil and worldwide is already established, and nothing is known on the feasibility of inoculation of PGPB to boost plant growth and forage biomass production under these conditions. In implanted pastures, there is also the limitation of inoculant application, as the only viable method would be via leaf-spray. However, it is worth mentioning that there are positive indications of success of leaf-spray of $A$. brasilense in maize (Fukami et al. 2016; Barbosa et al. 2021), encouraging to verify the feasibility on pastures.

Here we report the results of inoculation with A. brasilense strains CNPSo 2083 and CNPSo 2084, and of P. fluorescens strain CNPSo 2719, either on the 
seeds at sowing of new pastures, or via leaf-spray in established pastures without previous seed inoculation. We hypothesized that both strategies of inoculation would improve plant development, nutrient uptake, and forage biomass production by Urochloa, representing a key environmentally friendly and economically viable technology for pastures.

\section{Materials and methods}

Bacterial strains and inoculants

The strains of Azospirillum brasilense CNPSo 2083 (=Ab-V5) and CNPSo 2084 (=Ab-V6), and Pseudomonas fluorescens CNPSo 2719 (=CCTB 03) are currently deposited at the "Diazotrophic and Plant Growth Promoting Bacteria Culture Collection of Embrapa Soja" (World Federation Culture Collection, WFCC \# 1213, World Data Centre for Microorganisms, WDCM \#1054), in Londrina, State of Paraná, Brazil.

For the greenhouse experiments, inocula were prepared in the laboratory, at Embrapa Soja, by growing A. brasilense strains CNPSo 2083 and CNPSo 2084 separately in DYGS broth (Santos et al. 2020), at $28^{\circ} \mathrm{C}$, on a rotary shaker at $180 \mathrm{rpm}$. The growth curves of both strains with the correspondence of CFU (colony forming units) with O.D. (optical density) are available and currently used in the laboratory. After 5 days of growth the strains reached the stationary phase and based on the concentration (O.D.) of each strain, the inoculants were adjusted to $2 \times 10^{5} \mathrm{CFU} \mathrm{mL}^{-1}$ with DYGS broth. Following, the two inoculants were mixed to compose one inoculant carrying strains CNPSo 2083 and 2084. Strains were mixed because almost $100 \%$ of the 10.5 million doses of $A$. brasilense commercialized in Brazil in 2019/2020 carry both strains (Santos et al. 2021).

P. fluorescens strain CNPSo 2719 was grown in $30 \mathrm{~g} \mathrm{~L}^{-1}$ TSB (Tryptic Soy Broth, Acumedia ${ }^{\mathrm{TM}}$ ), at $28{ }^{\circ} \mathrm{C}$, on a rotary shaker at $180 \mathrm{rpm}$. As for A. brasilense, the growth curve of CFU X O.D. for strain CNPSo 2719 is available and currently used in the laboratory. After 5 days of growth, corresponding to the stationary phase, cell concentration was adjusted to $2 \times 10^{5} \mathrm{CFU} \mathrm{mL}^{-1}$ based on the O.D. In laboratory tests we verified that $P$. fluorescens CNPSo 2719 inhibits the growth of the two A. brasilense strains, and for this reason they were not combined in one inoculant.
For the field experiments, the inoculants were prepared in the laboratory of Total Biotecnologia Indústria e Comércio S.A. (Curitiba, State of Paraná, Brazil) containing A. brasilense strains CNPSo 2083 and CNPSo 2084 at the final concentration of $2 \times$

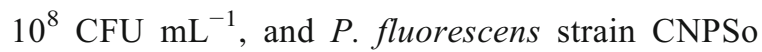
2719 at $1 \times 10^{8} \mathrm{CFU} \mathrm{mL}^{-1}$.

The RC (Rojo Congo) (Santos et al. 2020) and King B (King et al. 1954) media were used to confirm the concentrations of $A$. brasilense and P. fluorescens, respectively, in the inoculants used in every crop season. The identity of the strains in the inoculants was also confirmed in all experiments by verifying the DNA profiles of each strain by BOX-PCR analysis, as described by Chibeba et al. (2017).

\section{Greenhouse experiments}

Two greenhouse experiments were carried out under axenic conditions at the Experimental Station of Embrapa Soja, Londrina, Paraná State, southern Brazil $\left(23^{\circ} 11^{\prime} \mathrm{S}, 51^{\circ} 11^{\prime} \mathrm{W}\right)$. Plants were grown in modified Leonard jars (Yates et al. 2016), with $500 \mathrm{~cm}^{3}$ capacity, filled with a sterile mix composed of 3:1 coarse sand and ground coal, respectively. Nutrients were supplied in a sterile Hoagland's nutrient solution with $50 \%$ of $\mathrm{N}$ concentration and $\mathrm{pH}$ 6.5-7.0 (Hoagland and Arnon 1950), whenever necessary.

Urochloa brizantha (A.Rich.) R.D.Webster cultivar BRS Piatã and Urochloa decumbens (Stapf) R.D.Webster (syn. Urochloa eminii (Mez) Davidse) (Kewscience 2021) cultivar Basilisk were grown in one experiment each. Seeds were surface-disinfested by immersion in $70 \%$ ethanol for $1 \mathrm{~min}$, followed by $3 \%$ sodium hypochlorite for $3 \mathrm{~min}$, and six consecutive rinses in sterile distilled water. Six seeds were sown per jar. Five days after emergence, seedlings were thinned to one plant per jar. For both species, treatments consisted of a non-inoculated control (Control), seed inoculation with A. brasilense (SI Azo), leaf-spray inoculation with A. brasilense (LSI Azo), seed inoculation with $P$. fluorescens (SI Pf), and leaf-spray inoculation with $P$. fluorescens (LSI Pf). For seed inoculation, $1 \mathrm{~mL}(2 \times$ $10^{5} \mathrm{CFU} \mathrm{seed}^{-1}$ ) of the appropriate inoculum was added to the planting hole immediately after sowing. Leafspray inoculation was performed at the V3 growth stage (third leaf collared) (Moore et al. 1991), about 12 days after emergence (DAE). Spraying was performed with the aid of an aerograph atomizer previously calibrated, 
as described by Fukami et al. (2016), delivering $1 \mathrm{~mL}$ of inoculum per plant. For leaf-spray, the surface of the jars was covered with aluminum foil to avoid inoculum runoff from the leaves to the substrate. Both experiments had a completely randomized design with six replicates.

Plants were removed from jars 35 DAE, and roots and shoots were separated. Shoots were oven-dried at $50{ }^{\circ} \mathrm{C}$ until constant weight, and shoot biomass production was determined. Roots were washed in tap water and the root system volume was estimated by water displacement after immersion in a graduated cylinder. Total root length was assessed in fresh roots by the modified intersection method (Tennant 1975). Basically, fresh roots were randomly arranged on plates with $1 \times 1 \mathrm{~cm}$ grid squares and the intercepts of the roots with the vertical and horizontal grid lines were counted; total root length (TRL) was calculated by the formula TRL = $N \times 0.7857$, where $N$ is the number of intercepts and 0.7857 is the length conversion factor (Tennant 1975). Average root diameter was determined by the formula $2(\mathrm{~V} / \mathrm{L} \pi)^{0.5}$, where $\mathrm{V}$ and $\mathrm{L}$ correspond to the root system volume and total root length, respectively (Rondina et al. 2020).

Subsamples of approximately $0.3 \mathrm{~g}$ fresh fine roots $(\leq 2.0 \mathrm{~mm}$ diameter) were taken from each root system, stored in FAA solution (5\% formaldehyde, $5 \%$ acetic acid, 90\% ethyl alcohol-70\%, v:v:v). The number of root branches was then estimated by counting under a stereomicroscope at $20 \times$ magnification (Rondina et al. 2020). Root-hair incidence was determined by the presence or absence of root hairs on 100 fine root intersections by the gridline method (Zangaro et al. 2005), under a microscope, at $100 \times$ magnification.

The root systems were then oven-dried at $50{ }^{\circ} \mathrm{C}$ until constant weight. Specific root length was determined by the ratio between total root length and root dry weight. Root tissue density was calculated by the ratio between root dry weight and root volume.

\section{Field experiments}

Field experiments were carried out in two regions with distinct edaphoclimatic conditions in Brazil. In Londrina, Paraná State, at the Embrapa Soja Experimental Station $\left(23^{\circ} 11^{\prime} \mathrm{S}, 51^{\circ} 11^{\prime} \mathrm{W}\right)$, altitude of $620 \mathrm{~m}$, the experiments were conducted in four cropping seasons $(2012 / 2013,2013 / 2014,2014 / 2015$ and 2015/2016) in a Rhodic Eutrudox (Soil Survey Staff 2014). The climate is classified as humid, sub-tropical ( $C f a$, according to Köppen), with average minimum and maximum temperatures of 13.3 and $28.5^{\circ} \mathrm{C}$, respectively, and average annual rainfall of $1651 \mathrm{~mm}$. In Ponta Grossa, Paraná State, the experiments were conducted at the Experimental Station of Embrapa $\left(25^{\circ} 13^{\prime} \mathrm{S}, 50^{\circ} 1^{\prime} \mathrm{W}\right)$, altitude of $880 \mathrm{~m}$, during the first three cropping seasons $(2012 / 2013,2013 / 2014,2014 / 2015)$, in a Typic Acrudox (Soil Survey Staff 2014). The climate is classified as temperate with mild summer ( $C f b$, according to Köppen), with average minimum and maximum temperatures of 8.4 and $25.9{ }^{\circ} \mathrm{C}$, respectively, and annual rainfall of $1507 \mathrm{~mm}$. As the sites were located in experimental stations of Embrapa the soils were not degraded, and during the whole period of the experiments no other crop was grown in the sites.

Twenty subsamples were collected two months prior to sowing at the $0-20 \mathrm{~cm}$ soil layer and pooled to obtain a composite sample from each site, for chemical and granulometric analyses. Soil samples were dried at $45^{\circ} \mathrm{C}$ for $72 \mathrm{~h}$, sieved $(2 \mathrm{~mm})$ and analyzed according to Donagema et al. (2011). In the following years, each September, new soil samples were taken for chemical analysis. Results from chemical and granulometric analyses are presented in Table 1.

The main soil properties in Londrina were the high clay content $(>70 \%)$ and good fertility, with high contents of $\mathrm{P}, \mathrm{K}, \mathrm{Ca}+\mathrm{Mg}$, no $\mathrm{Al}$ and base saturation ranging from 60 to $74 \%$ in the four-year period of the experiments. The soil of Ponta Grossa had contrasting properties of high sand content $(>70 \%)$, very low $\mathrm{P}$ in comparison to Londrina, $\mathrm{Al}$ content although not high, and base saturation ranging from 44 to $52 \%$ in the threeyear period of the experiments (Table 1).

Whenever necessary, according to the soil analyses, lime was applied 40 days before sowing to correct soil acidity and attain a $70 \%$ base saturation. The amount of lime necessary was estimated after Embrapa Soja (2020).

At sowing and in September of each year, soil samples were taken at the $0-10 \mathrm{~cm}$ of soil layer for estimation of the population of diazotrophic microorganisms by the most probable number (MPN) method in semi-solid $\mathrm{NFb}$ medium, according to Döbereiner et al. (1976), and the results are presented in Table 1. The field experiments were conducted with Urochloa ruziziensis R. Germ. \& C.M. Evrard (syn. Urochloa eminii (Mez) Davidse (Kewscience 2021) cultivar Comum. It is worth mentioning that many changes in the taxonomy of Urochloa took place, and according to the Kewscience 
(2021) both U. ruziziensis and U. decumbens, this last one used in one of the greenhouse experiments are synonyms of Urochloa eminii. Seeds were sown at a density of $8 \mathrm{~kg} \mathrm{ha}^{-1}$ of seeds, with approximately $60 \%$ of cultural value. In each site and each year, two experiments were conducted side by side to verify both the effects of seed inoculation at pasture implantation, and of leaf-spray inoculation as a tool to promote growth and biomass production in pastures that had been established previously without any inoculation.

Field plots measured $4 \mathrm{~m} \times 5 \mathrm{~m}$, with planting rows spaced $0.5 \mathrm{~m}$ apart. All plots received basal fertilization with $400 \mathrm{~kg} \mathrm{ha}^{-1}$ of 00-20-20 formula (NPK, $80 \mathrm{~kg} \mathrm{ha}^{-1}$ of $\mathrm{P}_{2} \mathrm{O}_{5}$ and $80 \mathrm{~kg} \mathrm{ha}^{-1}$ of $\mathrm{K}_{2} \mathrm{O}$ ), and $40 \mathrm{~kg} \mathrm{ha}^{-1}$ of $\mathrm{N}$ as urea. The negative control consisted of the noninoculated treatment receiving $40 \mathrm{~kg} \mathrm{ha}^{-1}$ of $\mathrm{N}$ as urea at sowing. A further non-inoculated control, considered as the positive control, received $40 \mathrm{~kg} \mathrm{ha}^{-1}$ of $\mathrm{N}$ at sowing and supplementary $40 \mathrm{~kg} \mathrm{ha}^{-1}$ of $\mathrm{N}$, also as urea, 30 days after seedling emergence. In addition, for all inoculated treatments, an extra treatment that received supplementary $40 \mathrm{~kg} \mathrm{ha}^{-1}$ of $\mathrm{N}$ as urea 30 days after seedling emergence was included. All plots were sown at the same time. In summary, in each site and each year, two experiments were conducted side by side, one to verify the effects of seed inoculation in newly established pastures and the other one of leaf-spray inoculation in already established pastures that received no seed inoculation In Londrina, the experiments were conducted for four years and in Ponta Grossa for three years, but every year the experiments started from sowing. Every year all treatments received $40 \mathrm{~kg} \mathrm{ha}^{-1}$ of $\mathrm{N}$ as urea at sowing and each experiment consisted of the following treatments: $(i)$ negative control, with no inoculation and no supplementary N; (ii) positive control, with no inoculation, and receiving supplementary $40 \mathrm{~kg} \mathrm{ha}^{-1}$ of $\mathrm{N} 30$ days after emergence (DAE); (iii) inoculation with $A$. brasilense, with no supplementary $\mathrm{N}$; (iv) inoculation with $A$. brasilense, receiving supplementary $40 \mathrm{~kg} \mathrm{ha}^{-1}$ of N $30 \mathrm{DAE}$; $(v)$ inoculation with $P$. fluorescens, with no supplementary $\mathrm{N}$; and (vi) inoculation with $P$. fluorescens, receiving supplementary $40 \mathrm{~kg} \mathrm{ha}^{-1}$ of N 30 DAE. Every crop season all plots were established at the same time and the same parameters were evaluated in all experiments and crop seasons. All experiments were set in a completely randomized block design, with four replicates. The minimum dose of $40 \mathrm{~kg} \mathrm{ha}^{-1}$ of $\mathrm{N}$ was applied because there are no bacteria able to fully supply the $\mathrm{N}$ needs of non-legume plants, and the extra supply of $40 \mathrm{~kg} \mathrm{ha}^{-1}$ of $\mathrm{N}$ in half of the treatments aimed to verify possible positive or negative interactions with the bacteria.

When plots were designed to study the effects of seed inoculation, seed treatment was performed at sowing, at a rate of $20 \mathrm{~mL} \mathrm{~kg}^{-1}$ of seeds using inoculants with concentration adjusted to $2 \times 10^{8} \mathrm{CFU} \mathrm{mL}^{-1}$ of A. brasilense and $1 \times 10^{8} \mathrm{CFU} \mathrm{mL}^{-1}$ of $P$. fluorescens; as described before, sowing consisted of $8 \mathrm{~kg} \mathrm{ha}^{-1}$ of seeds. When plots were designed to study the effects of leaf inoculation, plants were allowed to grow for 30 days after seedling emergence and then sprayed with $300 \mathrm{~mL} \mathrm{ha}^{-1}$ of each inoculant, with the aid of a backpack sprayer. Spray inoculation always requires more inoculant, as there are losses due to irradiation and lower effectiveness to reach the roots.

Samples were taken 75 DAE, when the plants were with approximately $30 \mathrm{~cm}$ height. All plants within a $2.0 \mathrm{~m} \times 0.5 \mathrm{~m}$ central area of each plot were harvested for further analysis. Shoots were then separated and ovendried at $50{ }^{\circ} \mathrm{C}$ until constant weight for approximately $72 \mathrm{~h}$. Plant dry weight was employed to estimate shoot biomass production in $\mathrm{g} \mathrm{m}^{-2}$. After weighing, dry shoots were ground (20 mesh) and the concentrations of $\mathrm{N}, \mathrm{P}$, and $\mathrm{K}$ were determined according to Carmo et al. (2000).

Statistical analyses

Data from greenhouse and field experiments were subjected to normality and variance homogeneity tests. Root hair incidence data from the greenhouse experiments were transformed into arcsine $(\mathrm{x} / 100)^{0.5}$ before analysis. The dataset was submitted to ANOVA and, and when significant differences were detected $(p<0.05)$, means were compared with Tukey's (greenhouse experiments) and Duncan's (field experiments) tests. The statistical analysis used in the filed experiments aimed to attend to the Brazilian legislation for the registration of inoculants (MAPA 2011). All statistical analyses were performed in STATISTICA v. 12.0 (StatSoft Inc., Tulsa, OK, USA).

\section{Results}

Greenhouse experiments

It is important to comment that the greenhouse experiment was critical to evaluate root parameters. Under 
Table 1 Chemical properties $(0-20 \mathrm{~cm})$, granulometry ${ }^{\mathrm{a}}$ and population of diazotrophic bacteria $(0-10 \mathrm{~cm})$ in soils where the experiments were performed

\begin{tabular}{|c|c|c|c|c|c|c|c|c|c|c|}
\hline Site & $\begin{array}{l}\mathrm{pH} \\
\mathrm{CaCl}_{2}\end{array}$ & $\begin{array}{l}\mathrm{P} \\
\mathrm{mg} \mathrm{dm}\end{array}$ & $\mathrm{C}$ & $\begin{array}{l}\mathrm{H}+\mathrm{Al} \\
\mathrm{cmol}_{\mathrm{c}} \mathrm{dm}^{-}\end{array}$ & $\mathrm{Al}$ & $\mathrm{K}$ & $\mathrm{Ca}+\mathrm{Mg}$ & $\mathrm{CEC}^{\mathrm{b}}$ & $\begin{array}{l}\mathrm{BS}^{\mathrm{b}} \\
\%\end{array}$ & $\begin{array}{l}\mathrm{DB}^{\mathrm{c}} \\
\mathrm{n}^{\mathrm{o}} \mathrm{g}^{-1} \text { sol }\end{array}$ \\
\hline \multicolumn{11}{|c|}{$2012 / 2013$} \\
\hline Londrina & 5.44 & 23.5 & 13.1 & 4.22 & 0.00 & 0.76 & 5.65 & 10.63 & 60 & $9.5 \times 10^{5}$ \\
\hline Ponta Grossa & 4.76 & 1.11 & 21.5 & 6.22 & 0.00 & 0.31 & 4.67 & 11.2 & 44 & $7.0 \times 10^{6}$ \\
\hline \multicolumn{11}{|c|}{$2013 / 2014$} \\
\hline Londrina & 5.20 & 22.11 & 12.2 & 4.00 & 0.00 & 0.68 & 5.23 & 9.91 & 60 & $1.5 \times 10^{5}$ \\
\hline Ponta Grossa & 4.90 & 2.8 & 25.7 & 4.75 & 0.17 & 0.23 & 4.85 & 9.83 & 52 & $2.5 \times 10^{6}$ \\
\hline \multicolumn{11}{|c|}{$2014 / 2015$} \\
\hline Londrina & 5.59 & 21.00 & 13.80 & 3.28 & 0.00 & 1.13 & 7.51 & 11.92 & 72 & $9.5 \times 10^{5}$ \\
\hline Ponta Grossa & 5.50 & 2.55 & 17.90 & 4.90 & 0.07 & 0.44 & 4.01 & 9.35 & 48 & $2.5 \times 10^{5}$ \\
\hline \multicolumn{11}{|c|}{$2015 / 2016$} \\
\hline Londrina & 5.40 & 19.4 & 11.80 & 2.70 & 0.00 & 0.86 & 6.69 & 10.25 & 74 & $1.5 \times 10^{6}$ \\
\hline
\end{tabular}

${ }^{\mathrm{a}}$ Granulometry evaluated in the first year $\left(\mathrm{g} \mathrm{kg}^{-1}\right)$ : In Londrina, clay (710), silt (82), sand (208); in Ponta Grossa, clay (238), silt (30), sand (732)

${ }^{\mathrm{b}} \mathrm{CEC}=$ Cation Exchange Capacity $(\mathrm{H}+\mathrm{Al}+\mathrm{K}+\mathrm{Ca}+\mathrm{Mg})$; Base Saturation $(\mathrm{K}+\mathrm{Ca}+\mathrm{Mg} / \mathrm{CEC}) \times 100$; DB (diazotrophic bacteria)

field conditions, we were visualizing great differences in root growth, but it is not feasible to properly conduct a series of evaluations, especially in soils with high clay content, such as in Londrina. Under greenhouse conditions, for $U$. brizantha, one or more inoculation treatments improved root and shoot traits compared to the non-inoculated control, except for the specific root length and root mean diameter parameters (Table 2). Both seed and leaf-spray inoculation with both A. brasilense and P. fluorescens increased shoot and root biomass, root volume, and root tissue density. Seed inoculation with both bacteria and leaf inoculation with $P$. fluorescens increased root length, but only seed inoculation with $A$. brasilense increased root-hair incidence. Outstanding increases of up to 3 -fold in the number of root branches per plant were observed due to seed inoculation with $A$. brasilense and seed and leafspray with $P$. fluorescens (Table 2).

In the case of $U$. decumbens, all inoculation treatments significantly increased the total and specific root length, whereas only seed inoculation with A. brasilense increased the formation of root hairs (Table 2). Interestingly, both types of inoculation with A. brasilense resulted in thinner roots compared with the control. Root and shoot biomass, as well as root volume and root tissue density were not significantly affected by any inoculation treatment, despite a tendency towards increased shoot biomass. Again, outstanding increases of up to 2.7-fold in the number of root branches per plant were verified for all treatments, except for leaf-spray with A. brasilense (Table 2).

Field experiments

\section{Seed inoculation}

It is worth remembering that all treatments received $40 \mathrm{~kg} \mathrm{ha}^{-1}$ of $\mathrm{N}$-fertilizer at sowing, and that two noninoculated controls were included, one without further $\mathrm{N}$ fertilization (C) and the other receiving a supplementary dose of $40 \mathrm{~kg} \mathrm{ha}^{-1}$ of $\mathrm{N}$-fertilizer $30 \mathrm{DAE}(\mathrm{C}+\mathrm{N})$. Differences in shoot biomass yield from year to year were mainly attributed to different climatic conditions. When compared with the $\mathrm{C}+\mathrm{N}$ treatment, seed inoculation with $A$. brasilense resulted in statistically significant increases in shoot biomass yield in six out of seven experiments, whereas the inoculation with $P$. fluorescens resulted in increases in five out of seven experiments (Table 3).

Considering the average shoot biomass yield of all field trials performed in Londrina and Ponta Grossa, lower magnitude effects of seed inoculation with either bacterial species were observed when $\mathrm{N}$-fertilizer was applied only at sowing (Fig. 1). At both sites, seed inoculation with $A$. brasilense $+\mathrm{N}$ resulted in significant increases in shoot biomass over the $\mathrm{C}+\mathrm{N}$ control. Across all experiments of seed inoculation, the supplementary $40 \mathrm{~kg} \mathrm{ha}^{-1}$ of $\mathrm{N}$ increased shoot biomass, although not 
Table 2 Shoot biomass and root morphological traits in plants of Urochloa brizantha and Urochloa decumbens receiving different inoculation treatments with Azospirillum brasilense or
Pseudomonas fluorescens via seeds or leaf-spray. Plants grown under greenhouse conditions and harvested 35 days after emergence

\begin{tabular}{|c|c|c|c|c|c|c|c|c|c|}
\hline $\begin{array}{l}\text { Treatments } \\
\mathrm{a}\end{array}$ & $\begin{array}{l}\text { Shoot dry } \\
\text { weight } \\
\text { g plant }^{-1}\end{array}$ & $\begin{array}{l}\text { Root dry } \\
\text { weight } \\
\text { g plant }^{-1}\end{array}$ & $\begin{array}{l}\text { Root } \\
\text { volume } \\
\mathrm{cm}^{3} \\
\text { plant }^{-1}\end{array}$ & $\begin{array}{l}\text { Total root } \\
\text { length } \\
\text { m plant }^{-1}\end{array}$ & $\begin{array}{l}\text { Specific root } \\
\text { length } \\
\mathrm{m} \mathrm{g}^{-1}\end{array}$ & $\begin{array}{l}\text { Root tissue } \\
\text { density } \\
\mathrm{mg} \mathrm{cm}^{-3}\end{array}$ & $\begin{array}{l}\text { Root mean } \\
\text { diameter } \\
\mu \mathrm{m}\end{array}$ & $\begin{array}{l}\text { Root-hair } \\
\text { incidence } \\
\%\end{array}$ & $\begin{array}{l}\text { Root branches } \\
\text { per plant }\end{array}$ \\
\hline
\end{tabular}

Urochloa brizantha

$\begin{array}{llllllllll}\text { Control } & 2.03 \mathrm{~b} & 1.47 \mathrm{c} & 5.17 \mathrm{c} & 92 \mathrm{c} & 62.3 \mathrm{n} . \mathrm{s} . & 262 \mathrm{~b} & 266 \text { n.s. } & 59.6 \mathrm{~b} & 15,874 \mathrm{~b} \\ \text { SI Azo } & 3.38 \mathrm{a} & 2.84 \mathrm{~b} & 9.64 \mathrm{~b} & 168 \mathrm{~b} & 59.3 & 294 \mathrm{a} & 274 & 75.6 \mathrm{a} & 36,913 \mathrm{a} \\ \text { LSI Azo } & 3.49 \mathrm{a} & 2.64 \mathrm{~b} & 8.99 \mathrm{~b} & 139 \mathrm{bc} & 52.5 & 292 \mathrm{a} & 294 & 70.0 \mathrm{ab} & 33,229 \mathrm{ab} \\ \text { SI Pf } & 4.01 \mathrm{a} & 3.86 \mathrm{a} & 13.3 \mathrm{a} & 231 \mathrm{a} & 57.1 & 297 \mathrm{a} & 277 & 64.4 \mathrm{ab} & 48,831 \mathrm{a} \\ \text { LSI Pf } & 3.77 \mathrm{a} & 3.42 \mathrm{ab} & 11.5 \mathrm{ab} & 159 \mathrm{~b} & 47.8 & 300 \mathrm{a} & 301 & 63.2 \mathrm{~b} & 38,719 \mathrm{a} \\ \text { CV (\%) } & 30.0 & 33.0 & 27.7 & 30.2 & 18.2 & 3.98 & 9.87 & 14.9 & 32.7 \\ \text { Urochloa decumbens } & & & & & & & & \\ \text { Control } & 2.81 \text { n.s. } & 1.43 \text { n.s. } & 8.13 \text { n.s. } & 88 \mathrm{~b} & 77.3 \mathrm{~b} & 167 \text { n.s. } & 310 \mathrm{a} & 42.8 \mathrm{~b} & 16,767 \mathrm{c} \\ \text { SI Azo } & 3.47 & 1.20 & 8.64 & 153 \mathrm{a} & 125 \mathrm{a} & 140 & 274 \mathrm{~b} & 60.1 \mathrm{a} & 38,048 \mathrm{ab} \\ \text { LSI Azo } & 3.24 & 1.16 & 8.89 & 155 \mathrm{a} & 134 \mathrm{a} & 139 & 270 \mathrm{~b} & 37.6 \mathrm{~b} & 32,241 \mathrm{~b} \\ \text { SI Pf } & 3.55 & 1.38 & 10.6 & 156 \mathrm{a} & 114 \mathrm{a} & 121 & 308 \mathrm{a} & 41.6 \mathrm{~b} & 44,339 \mathrm{a} \\ \text { LSI Pf } & 3.62 & 1.44 & 11.0 & 191 \mathrm{a} & 116 \mathrm{a} & 126 & 289 \mathrm{ab} & 45.2 \mathrm{~b} & 45,262 \mathrm{a} \\ \text { CV (\%) } & 27.8 & 31.8 & 26.9 & 29.3 & 25.7 & 18.4 & 8.49 & 13.5 & 22.1\end{array}$

${ }^{a}$ Control = non-inoculated; SI Azo = seed inoculation with A. brasilense; LSI Azo = leaf-spray inoculation with A. brasilense at plant V3 growth stage; $\mathrm{SI} \mathrm{Pf}=$ seed inoculation with $P$. fluorescens; LSI Pf = leaf-spray inoculation with $P$. fluorescens at plant V3 growth stage

${ }^{\mathrm{b}}$ Data represent the means of six replicates, and when followed by different letters differ from each other by Tukey's test at $p \leq 0.05$; n.s. statistically non-significant

statistically different, by only $3.1 \%$ relative to the $\mathrm{C}$ treatment, in contrast to $22.1 \%$ and $21.6 \%$, statistically different, obtained with seed inoculation with A. brasilense or P. fluorescens with the same amount of supplementary N, respectively (Fig. 1, Table 3).

Foliar analyses revealed that seed inoculation with A. brasilense significantly increased the $\mathrm{N}$ and $\mathrm{K}$ concentrations in tissues, in comparison with both $\mathrm{C}$ and $\mathrm{C}+\mathrm{N}$ controls, at both locations, but no effects were observed on P concentration (Table 4). Seed inoculation with $P$. fluorescens significantly increased $\mathrm{P}$ and $\mathrm{K}$ concentrations in tissues, in comparison with both $\mathrm{C}$ and $\mathrm{C}+\mathrm{N}$ controls, but no effects on $\mathrm{N}$ concentrations were observed (Table 4).

\section{Leaf-spray inoculation}

In the case of pastures that had not received inoculants at sowing, when compared with the $\mathrm{C}$ treatment, leafspray inoculation with $A$. brasilense significantly increased the shoot biomass in three out of seven experiments, whereas leaf-spray inoculation with
$P$. fluorescens promoted positive responses in four out of seven experiments (Table 5).

Just as observed with seed inoculation, the benefits of leaf-spray inoculation were more pronounced when plants had also received a supplementary dose of $\mathrm{N}$ fertilizer. On average, leaf-spray inoculation with A. brasilense or $P$. fluorescens on grown plants that received a supply of $40 \mathrm{~kg} \mathrm{ha}^{-1}$ of $\mathrm{N} 30$ days after emergence resulted in $20.8 \%$ and $14.3 \%$ increases in shoot biomass, respectively (Fig. 1, Table 5).

At both locations, leaf-spray inoculation with A. brasilense significantly increased $\mathrm{N}$ and $\mathrm{K}$ concentrations in leaf tissues, but no effects were observed on $\mathrm{P}$ concentration (Table 4). Once again, on the other hand, leaf-spray inoculation with $P$. fluorescens increased $\mathrm{P}$ and $\mathrm{K}$, but not $\mathrm{N}$ concentrations, at both locations (Table 4).

\section{Overall results}

In summary, considering the average of seven field trials performed in four crop seasons, seed inoculation with 
Table 3 Shoot biomass $\left(\mathrm{g} \mathrm{m}^{-2}\right)$ of Urochloa ruziziensis in response to seed inoculation with Azospirillum brasilense or Pseudomonas fluorescens in field trials performed at two sites in southern Brazil. All treatments received $40 \mathrm{~kg} \mathrm{ha}^{-1}$ of $\mathrm{N}$ at sowing, and half of the treatments supplementary $\mathrm{N}$-fertilizer $\left(40 \mathrm{~kg} \mathrm{ha}^{-1}\right.$ of N) 30 days after emergence. Harvest performed 75 days after emergence

\begin{tabular}{|c|c|c|c|c|c|c|c|c|}
\hline Treatment & $\begin{array}{l}\text { Supplementary } \\
\text { N-fertilizer }\end{array}$ & $\begin{array}{l}2012 / \\
2013\end{array}$ & $\begin{array}{l}2013 / \\
2014\end{array}$ & $\begin{array}{l}2014 / \\
2015\end{array}$ & $\begin{array}{l}2015 / \\
2016\end{array}$ & Average $^{a}$ & Increase $^{b}$ & Increase ${ }^{c}$ \\
\hline \multicolumn{9}{|c|}{ Londrina } \\
\hline Control & No & $214 b^{d}$ & $212 b$ & $132 \mathrm{~b}$ & $146 \mathrm{~b}$ & $176 \mathrm{c}$ & & \\
\hline Control & Yes & $212 b$ & $213 b$ & $156 \mathrm{~b}$ & $141 \mathrm{~b}$ & $181 \mathrm{c}$ & +2.8 & \\
\hline Azospirillum brasilense & No & $221 \mathrm{~b}$ & $250 \mathrm{a}$ & $142 \mathrm{~b}$ & $183 \mathrm{a}$ & $199 \mathrm{~b}$ & +13.1 & \\
\hline Azospirillum brasilense & Yes & $302 \mathrm{a}$ & $258 \mathrm{a}$ & $188 \mathrm{a}$ & $186 \mathrm{a}$ & $234 \mathrm{a}$ & & +29.3 \\
\hline Pseudomonas fluorescens & No & $233 \mathrm{~b}$ & $240 \mathrm{ab}$ & $215 \mathrm{a}$ & $151 \mathrm{~b}$ & $210 \mathrm{~b}$ & +19.3 & \\
\hline Pseudomonas fluorescens & Yes & $297 \mathrm{a}$ & $243 \mathrm{ab}$ & $203 \mathrm{a}$ & $181 \mathrm{a}$ & $231 \mathrm{a}$ & & +27.6 \\
\hline $\mathrm{CV}(\%)$ & & 11.2 & 10.1 & 15.7 & 9.8 & 12.5 & & \\
\hline \multicolumn{9}{|c|}{ Ponta Grossa } \\
\hline Control & No & $123 \mathrm{a}$ & $327 \mathrm{~b}$ & $195 \mathrm{~b}$ & & $215 \mathrm{~b}$ & & \\
\hline Control & Yes & $122 \mathrm{a}$ & $328 \mathrm{~b}$ & $219 \mathrm{~b}$ & & $223 \mathrm{~b}$ & +3.7 & \\
\hline Azospirillum brasilense & No & $113 \mathrm{a}$ & $327 \mathrm{~b}$ & $270 \mathrm{a}$ & & $237 \mathrm{ab}$ & +10.2 & \\
\hline Azospirillum brasilense & Yes & $129 \mathrm{a}$ & $380 \mathrm{a}$ & $261 \mathrm{a}$ & & $257 \mathrm{a}$ & & +15.2 \\
\hline Pseudomonas fluorescens & No & $114 \mathrm{a}$ & $321 \mathrm{~b}$ & $198 \mathrm{~b}$ & & $211 b$ & -1.9 & \\
\hline Pseudomonas fluorescens & Yes & $104 \mathrm{a}$ & $377 \mathrm{a}$ & $289 \mathrm{a}$ & & $257 \mathrm{a}$ & & +15.2 \\
\hline $\mathrm{CV}(\%)$ & & 16.8 & 9.9 & 10.3 & & 11.8 & & \\
\hline
\end{tabular}

${ }^{a}$ Average values considering all years

${ }^{\mathrm{b}}$ Increase (\%) in comparison to the Control treatment

${ }^{\mathrm{c}}$ Increase (\%) in comparison to the Control treatment + supplementary N

${ }^{\mathrm{d}}$ Means of four replicates and when followed by different letters denote statistical differences for each parameter in each site (Duncan, $p \leq$ $0.05)$

A. brasilense or $P$. fluorescens in brachiarias receiving the basal level of $40 \mathrm{~kg} \mathrm{ha}^{-1}$ of $\mathrm{N}$ fertilizer increased shoot biomass yield by $11.4 \%$ and $8.8 \%$, respectively, and by $22.1 \%$ and $21.6 \%$ when receiving extra Nfertilizer 30 DAE, respectively (Fig. 1). Impacting increases were also found with leaf-spray inoculation, of $12.7 \%$ and $14.0 \%$ with $A$. brasilense or P. fluorescens in the basal level of $\mathrm{N}$-fertilizer, increasing to $20.8 \%$ and $14.3 \%$, respectively, with the extra supply of $\mathrm{N}$-fertilizer (Fig. 1).

\section{Discussion}

Modern agriculture demands improvement in the efficiency of food production, without threatening the fragile planet equilibrium. Several biotechnological tools have been developed and employed to make agriculture more efficient (Mannion and Morse 2012; Zhao et al. 2020). For example, the utilization of PGPB (Bishnoi 2015) that stimulates plant growth and crop yield by an array of mechanisms (Hungria and Mendes 2015; Souza et al. 2015; Goswami et al. 2016; Fukami et al. 2018b; Santos et al. 2019). In this study, we report the results of experiments performed under greenhouse conditions and in four years of field experiments to evaluate the effects PGPB on growth, biomass production and nutrient concentration in Urochloa spp. The experiments were carried out under two situations: seeds inoculated with PGPB (A. brasilense or P. fluorescens) at the time of pasture sowing, and leaf-spray with the same strains in pastures that were already established from noninoculated seeds.

In relation to the microorganisms used in this study, A. brasilense strains CNPSo 2083 and CNPSo 2084 were isolated in southern Brazil and first released in 

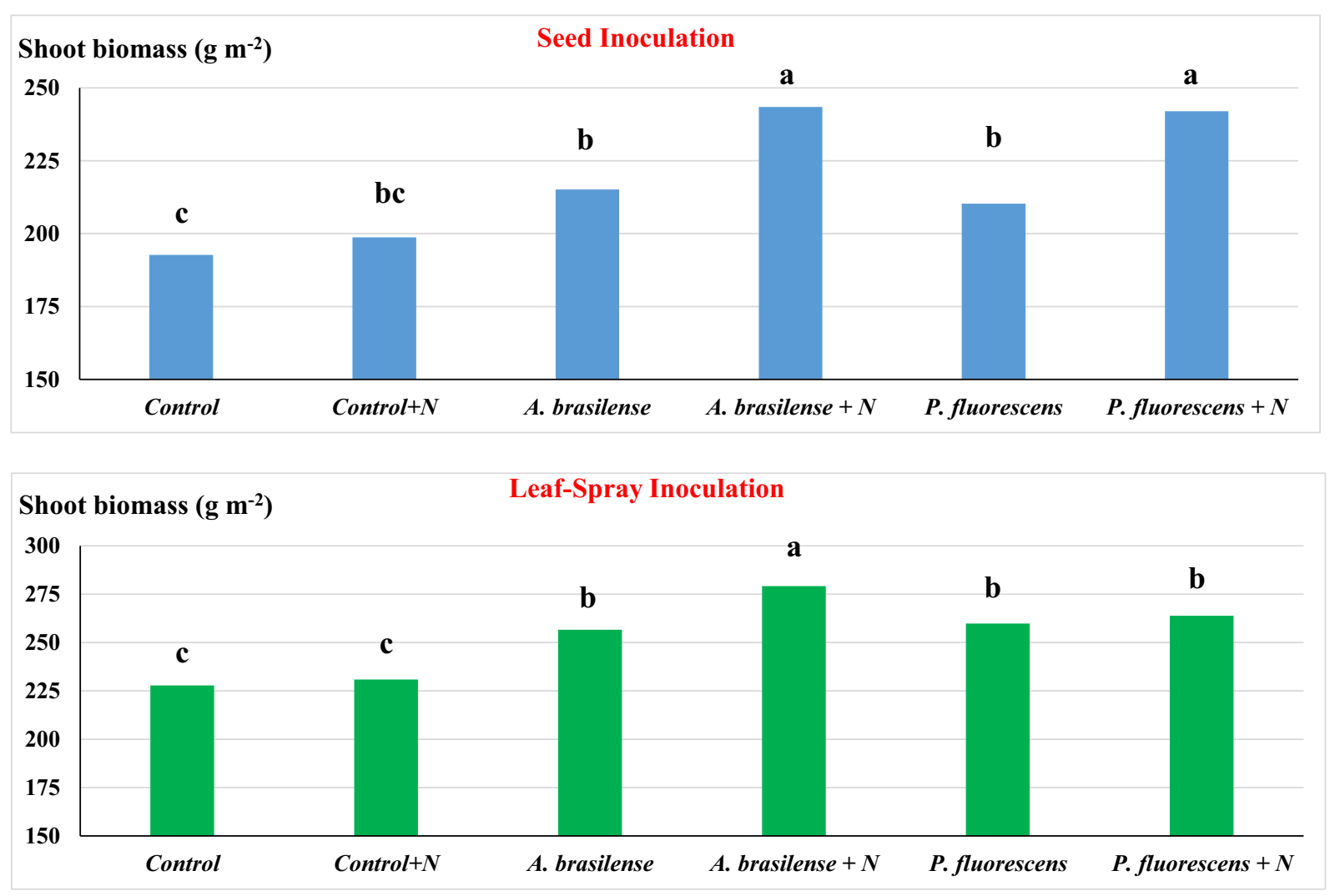

Fig. 1 Average results of shoot biomass $\left(\mathrm{g} \mathrm{m}^{-2}\right)$ of seven field experiments performed in two sites of southern Brazil with Urochloa ruziziensis inoculated with Azospirillum brasilense or Pseudomonas fluorescens via seeds or leaf-spray. Plants receiving a basal level of $40 \mathrm{~kg} \mathrm{ha}^{-1}$ of $\mathrm{N}$, without or with $(+\mathrm{N})$ a

supplementary dose of $40 \mathrm{~kg} \mathrm{ha}^{-1}$ of $\mathrm{N}$-fertilizer 30 days after emergence. Data represent the means of seven field trials, each with four replicates, and when followed by different letters differ from each other by Tukey's test at $p \leq 0.05$

commercial inoculants in 2009 for the maize and wheat crops (Hungria et al. 2010), following recommendations for rice (Oryza sativa L.), brachiarias (seeds) and coinoculation of the legumes soybean [Glycine max (L.) Merr.] and common bean (Phaseolus vulgaris L.) (Hungria et al. 2013, 2016; Santos et al. 2021). In ten years, more than 200 studies have been published with strains CNPSo 2083 and CNPSo 2084 (Barbosa et al. 2021; Santos et al. 2021) and plant-growth promotion has been associated mainly with the high levels of phytohormones synthesized by the strains, with an emphasis on indole-3-acetic acid (IAA) (Fukami et al. 2017), greatly improving root growth and the uptake of water and nutrients. The strains also contribute via the biological nitrogen fixation process, and induction of mechanisms of resistance to abiotic and biotic stresses (Fukami et al. 2018b; Santos et al. 2021), and the genes for such properties were confirmed in their genomes
(Hungria et al. 2018). The selection of $P$. fluorescens strain CNPSo 2719 is more recent, with less information available. The strain was isolated in a soil of Paraná State, southern Brazil, selected as a PGPB for the maize crop and used in commercial inoculants for this crop since 2019 (Sandini et al. 2019). In six field experiments performed with maize, the strain improved growth and yield parameters and allowed a reduction of $25 \%$ of $\mathrm{N}$ fertilizer (Sandini et al. 2019). In addition, unpublished results from our laboratory confirmed that $P$. fluorescens CNPSo 2719 is highly positive in the synthesis of siderophores, phosphate solubilization $\left(\mathrm{CaHPO}_{4} 2 \mathrm{H}_{2} \mathrm{O}\right)$, and of 1-aminocyclopropane-1carboxylate (ACC) deaminase, properties that were not detected in the two A. brasilense strains; the $P$. fluorescens strain also synthesizes IAA, although in lower quantities than the two A. brasilense strains (data not shown). 
Table $4 \mathrm{~N}$, P e K concentrations $\left(\mathrm{g} \mathrm{kg}^{-1}\right)$ in shoot biomass of Urochloa ruziziensis in response to seed or leaf-spray inoculation with Azospirillum brasilense or Pseudomonas fluorescens in field trials performed at two sites in southern Brazil. All treatments received $40 \mathrm{~kg} \mathrm{ha}^{-1}$ of $\mathrm{N}$ at sowing and half of the treatments supplementary $\mathrm{N}$-fertilizer ( $40 \mathrm{~kg} \mathrm{ha}^{-1}$ of $\mathrm{N}$ ) 30 days after emergence. Harvest performed 75 days after emergence

\begin{tabular}{|c|c|c|c|c|c|c|c|}
\hline Treatment & Supplementary N-fertilizer & $\mathrm{N}$ & $\mathrm{P}$ & \multirow[t]{2}{*}{$\mathrm{K}$} & $\mathrm{N}$ & $\mathrm{P}$ & \multirow{2}{*}{$\begin{array}{c}\mathrm{K} \\
\text { - Leaf-spray inocula- }\end{array}$} \\
\hline & & \multicolumn{2}{|c|}{ inoculation- } & & \multicolumn{2}{|c|}{ tion $\longrightarrow$} & \\
\hline \multicolumn{8}{|c|}{ Londrina } \\
\hline Control & No & $17.8 \mathrm{c}^{\mathrm{a}}$ & $2.2 \mathrm{~b}$ & $29.1 \mathrm{~b}$ & $16.7 \mathrm{~d}$ & $2.0 \mathrm{c}$ & $28.3 \mathrm{~d}$ \\
\hline Control & Yes & $20.2 \mathrm{~b}$ & $2.3 \mathrm{~b}$ & $29.5 \mathrm{~b}$ & $19.3 \mathrm{c}$ & $2.1 \mathrm{c}$ & $29.4 \mathrm{c}$ \\
\hline Azospirillum brasilense & No & $20.3 \mathrm{~b}$ & $2.2 \mathrm{~b}$ & $31.9 \mathrm{a}$ & $20.5 \mathrm{~b}$ & $2.2 \mathrm{c}$ & $32.0 \mathrm{~b}$ \\
\hline Azospirillum brasilense & Yes & $22.1 \mathrm{a}$ & $2.3 \mathrm{~b}$ & $32.5 \mathrm{a}$ & $22.9 \mathrm{a}$ & $2.2 \mathrm{c}$ & $32.2 \mathrm{ab}$ \\
\hline Pseudomonas fluorescens & No & $17.5 \mathrm{c}$ & $2.9 \mathrm{a}$ & $32.1 \mathrm{a}$ & $17.0 \mathrm{~d}$ & $2.7 \mathrm{~b}$ & $32.7 \mathrm{a}$ \\
\hline Pseudomonas fluorescens & Yes & $17.8 \mathrm{c}$ & $3.1 \mathrm{a}$ & $32.7 \mathrm{a}$ & $17.1 \mathrm{~d}$ & $2.9 \mathrm{a}$ & $32.8 \mathrm{a}$ \\
\hline $\mathrm{CV}(\%)$ & & 7.3 & 5.9 & 7.1 & 7.5 & 5.3 & 6.8 \\
\hline \multicolumn{8}{|c|}{ Ponta Grossa } \\
\hline Control & No & $10.9 \mathrm{c}$ & $1.9 \mathrm{c}$ & $24.1 \mathrm{c}$ & $11.1 \mathrm{~d}$ & $2.0 \mathrm{~b}$ & $23.8 \mathrm{~b}$ \\
\hline Control & Yes & $11.5 \mathrm{~b}$ & $2.0 \mathrm{bc}$ & $25.8 \mathrm{~b}$ & $11.9 \mathrm{bc}$ & $2.1 \mathrm{~b}$ & $24.0 \mathrm{~b}$ \\
\hline Azospirillum brasilense & No & $11.9 \mathrm{~b}$ & $1.9 \mathrm{c}$ & $26.2 \mathrm{~b}$ & $12.3 \mathrm{~b}$ & $2.0 \mathrm{~b}$ & $27.9 \mathrm{a}$ \\
\hline Azospirillum brasilense & Yes & $13.0 \mathrm{a}$ & $2.1 \mathrm{~b}$ & $28.7 \mathrm{a}$ & $13.3 \mathrm{a}$ & $2.0 \mathrm{~b}$ & $28.0 \mathrm{a}$ \\
\hline Pseudomonas fluorescens & No & $11.0 \mathrm{c}$ & $2.2 \mathrm{ab}$ & $26.1 \mathrm{~b}$ & $11.5 \mathrm{~cd}$ & $2.5 \mathrm{a}$ & $27.6 \mathrm{a}$ \\
\hline Pseudomonas fluorescens & Yes & $11.2 \mathrm{bc}$ & $2.4 \mathrm{a}$ & $28.6 \mathrm{a}$ & $12.0 \mathrm{bc}$ & $2.7 \mathrm{a}$ & $28.3 \mathrm{a}$ \\
\hline $\mathrm{CV}(\%)$ & & 8.1 & 4.8 & 6.8 & 7.4 & 5.7 & 6.5 \\
\hline
\end{tabular}

\footnotetext{
${ }^{a}$ Data represent the means four field trials performed in Londrina and three in Ponta Grossa, each with four replicates, with seed or leaf-spray (at the V3 growth stage) inoculation, and when followed by different letters denote statistical differences for each nutrient in each site (Duncan, $p \leq 0.05$ )
}

In the greenhouse experiments under axenic conditions, seed inoculation with both PGPB increased total length of the root system and the number of root branches of $U$. brizantha and $U$. decumbens. The ability of some A. brasilense strains to produce and secrete auxins that stimulate the activity of root apexes, cell elongation, and root branching has been documented (Barbieri and Galli 1993; Duca et al. 2014; Maheshwari et al. 2015; Cassán et al. 2020; Rondina et al. 2020), and our results confirm previous reports in other grasses (Fukami et al. 2017, 2018a) showing that the strains CNPSo 2083 and CNPSo 2084 may exert the same activity. In addition, $A$. brasilense produces and releases nitric oxide, which acts as a signaling molecule in the pathway that induces root branching (MolinaFavero et al. 2008).

Root growth and branching were positively influenced by $P$. fluorescens, a species of PGPB that also produces auxins (Kochar et al. 2011; Maheshwari et al. 2015), besides cytokinin and the enzyme ACCdeaminase in the rhizosphere (Pallai et al. 2012), all involved in the regulation of root and plant growth mechanisms. Ortiz-Castro et al. (2020) have demonstrated that $P$. fluorescens produces cyclopeptides that regulate auxin-responsive genes in roots, and the authors have proposed this as the key mechanism by which this PGPB modulates plant root morphology. In the case of strain CNPSo 2719, we detected synthesis of IAA and also ACC-deaminase (data not shown) contributing to improve root architecture.

Longer and more branched roots can explore more efficiently larger volumes of soil, resulting in improved water and nutrient uptake by plants (Hodge 2004; York et al. 2013). In addition, increased root proliferation may help seedlings to establish faster and survive under nutrient and water limitations (York et al. 2013; White 2019). This is significant for forage grasses that are commonly established in degraded, low-fertility and organic matter-poor soils in the tropics (Oliveira et al. 2004; Dias-Filho 2014). In our experiments, inoculation with either species improved the root system architecture, thus corroborating their importance as PGPB. 
Table 5 Shoot biomass $\left(\mathrm{g} \mathrm{m}^{-2}\right)$ of Urochloa ruziziensis in response to leaf-spray inoculation at the V3 growth stage with Azospirillum brasilense or Pseudomonas fluorescens in field trials performed at two sites in southern Brazil. All treatments received
$40 \mathrm{~kg} \mathrm{ha}^{-1}$ of $\mathrm{N}$ at sowing and half of the treatments supplementary $\mathrm{N}$-fertilizer $\left(40 \mathrm{~kg} \mathrm{ha}^{-1}\right.$ of $\left.\mathrm{N}\right) 30$ days after emergence. Harvest performed 75 days after emergence and 45 days after leaf spraying

\begin{tabular}{|c|c|c|c|c|c|c|c|c|}
\hline Tratamento & $\begin{array}{l}\text { Supplementary N- } \\
\text { fertilizer }\end{array}$ & $\begin{array}{l}2012 / \\
2013\end{array}$ & $\begin{array}{l}2013 / \\
2014\end{array}$ & $\begin{array}{l}2014 / \\
2015\end{array}$ & $\begin{array}{l}2015 / \\
2016\end{array}$ & Average $^{a}$ & Increase $^{b}$ & Increase $^{c}$ \\
\hline \multicolumn{9}{|c|}{ Londrina } \\
\hline Control & No & $267 b c^{d}$ & $213 b$ & $274 \mathrm{~b}$ & $237 \mathrm{~b}$ & $248 \mathrm{~b}$ & & \\
\hline Control & Yes & $293 \mathrm{~b}$ & $206 \mathrm{~b}$ & $275 \mathrm{~b}$ & $236 \mathrm{~b}$ & $253 \mathrm{~b}$ & +2.0 & \\
\hline Azospirillum brasilense & No & $226 \mathrm{c}$ & $238 \mathrm{ab}$ & $358 \mathrm{a}$ & $289 \mathrm{a}$ & $278 \mathrm{ab}$ & +12.1 & \\
\hline Azospirillum brasilense & Yes & $342 \mathrm{a}$ & $255 \mathrm{a}$ & $339 \mathrm{a}$ & $295 \mathrm{a}$ & $308 \mathrm{a}$ & & +21.7 \\
\hline $\begin{array}{r}\text { Pseudomonas } \\
\text { fluorescens }\end{array}$ & No & $234 \mathrm{c}$ & $283 \mathrm{a}$ & $325 \mathrm{ab}$ & $285 \mathrm{a}$ & $282 \mathrm{ab}$ & +13.7 & \\
\hline $\begin{array}{l}\text { Pseudomonas } \\
\text { fluorescens }\end{array}$ & Yes & $341 \mathrm{a}$ & $270 \mathrm{a}$ & $280 \mathrm{~b}$ & $282 \mathrm{a}$ & $293 \mathrm{a}$ & & +15.8 \\
\hline $\mathrm{CV}(\%)$ & & 12.3 & 10.8 & 13.1 & 10.1 & 12.0 & & \\
\hline \multicolumn{9}{|c|}{ Ponta Grossa } \\
\hline Control & No & $139 \mathrm{c}$ & $243 \mathrm{~b}$ & $222 b$ & & $201 \mathrm{a}$ & & \\
\hline Control & Yes & $134 \mathrm{c}$ & $245 b$ & $227 \mathrm{~b}$ & & $202 \mathrm{a}$ & +0.5 & \\
\hline Azospirillum brasilense & No & $141 \mathrm{bc}$ & $220 \mathrm{~b}$ & $294 \mathrm{a}$ & & $218 \mathrm{a}$ & +8.5 & \\
\hline Azospirillum brasilense & Yes & $164 \mathrm{ab}$ & $282 \mathrm{a}$ & $277 \mathrm{a}$ & & $241 \mathrm{a}$ & & +19.3 \\
\hline $\begin{array}{l}\text { Pseudomonas } \\
\text { fluorescens }\end{array}$ & No & $167 \mathrm{ab}$ & $226 \mathrm{~b}$ & $273 \mathrm{a}$ & & $222 \mathrm{a}$ & +10.4 & \\
\hline $\begin{array}{r}\text { Pseudomonas } \\
\text { fluorescens }\end{array}$ & Yes & $182 \mathrm{a}$ & $221 \mathrm{~b}$ & $271 \mathrm{a}$ & & $225 \mathrm{a}$ & & +11.4 \\
\hline $\mathrm{CV}(\%)$ & & 11.9 & 11.5 & 10.6 & & 11.6 & & \\
\hline
\end{tabular}

${ }^{a}$ Average values considering all years

${ }^{\mathrm{b}}$ Increase (\%) in comparison to the Control treatment

${ }^{\mathrm{c}}$ Increase (\%) in comparison to the Control treatment + supplementary N

${ }^{\mathrm{d}}$ Means of four replicates and when followed by different letters denote statistical differences for each nutrient in each site (Duncan, $p \leq$ $0.05)$

In general, inoculation with both PGPB improved root system architecture, with greater potential for soil exploitation to support plants able to produce larger amounts of forage biomass. Improvements in root architecture parameters by inoculation with $A$. brasilense (e.g. root hair incidence by seed inoculation), $P$. fluorescens (e.g. root volume by seed or leaf-spray inoculation), or both genera and inoculation methods (e.g. total root length) are key to improve water and nutrients uptake (Haling et al. 2013, 2016) that frequently limit forage biomass production in tropical soils (Garcia-Montiel et al. 2000; Dias-Filho 2014). In addition, the greater root hair incidence results in the expansion of the rhizosphere, favoring root interaction with other beneficial soil microorganisms (Lynch 2019).

The effects of leaf-spray inoculation with either PGPB, especially on the traits related to root morphology, were similar to those obtained with seed inoculation. It is worth remembering that under greenhouse conditions the soils were covered with aluminum foil, such that the effects should come from shoots. Systemic signaling pathways from shoots to roots in response to the inoculation with $A$. brasilense have been previously shown in maize (Fukami et al. 2017, 2018b), and soybean (Puente et al. 2018, 2019), demonstrating that inoculation with $A$. brasilense in established plants may still stimulate the root system, benefiting plant establishment and shoot biomass production. In addition, in previous studies, when both strains of A. brasilense were applied via foliar spray in maize, cell recovery in leaves was very low and promotion of plant growth was confirmed with spray of both cells and cellfree metabolites (Fukami et al. 2017). Altogether, our results strongly suggest that also in Urochloa, the 
mechanisms related to foliar spray may be related mainly to systemic signaling from shoots to roots.

In the field, both strategies of inoculation, via seeds or leaf-spray, with both PGPB increased shoot biomass yield of $U$. ruziziensis at the two locations, confirming that PGPB can also be employed in forage crops, besides grain crops such as soybean, maize, wheat, among others (Hungria et al. 2016; Santos et al. 2019). Soil fertility conditions were different, with an emphasis on the higher content of $\mathrm{P}$ and clay in Londrina (Table 1), but benefits were confirmed in both sites. Positive results of forage inoculation with PGPB have been previously reported, e.g. for Bermuda grass (Cynodon dactylon L.) (Aguirre et al. 2018), fescue (Festuca arundinacea Schreb) (Monk et al. 2009), and kikuio grass (Pennisetum clandestinum Hochst) (Criollo et al. 2012).

Seed inoculation of tropical forages such as Urochloa spp. and Megathyrsus. maximus with the same strains of $A$. brasilense (Pedreira et al. 2017; Leite et al. 2019a, b), with A. brasilense and Rhizobium tropici CIAT 899 (Sá et al. 2019a, b), and with A. brasilense and P. fluorescens (Duarte et al. 2020) stimulated plant height, tillering, root biomass, shoot elongation, relative chlorophyll index, $\mathrm{N}$ concentrations in leaves, and plant biomass. In addition, seed inoculation with both strains of $A$. brasilense promoted increases in the $\mathrm{N}$ concentration of Urochloa sp., equivalent to an application of $40 \mathrm{~kg} \mathrm{ha}^{-1}$ of $\mathrm{N}$ (Hungria et al. 2016). The stimulus of plant growth and biomass yield resulting from inoculation may help a faster forage recovery after livestock grazing, making possible to enter the pasture with livestock earlier and more times during the season. This is a significant gain in terms of the efficiency of forage production, opening an avenue to increase animal protein production without having to clear more land for pasture implantation.

There was no information about the benefits of leafspray inoculation in pastures that have been sown with non-inoculated seeds. Previous studies (Fukami et al. 2016, 2017; Puente et al. 2018) have demonstrated a systemic action of leaf-spray of $A$. brasilense on maize and wheat. Rondina et al. (2020) postulated that such systemic action resulted in improved plant root growth. Our greenhouse experiments have clearly demonstrated that leaf spray with both PGPB has the same effect on Urochloa spp., and we have observed that, in the field, U. ruziziensis responded significantly to leaf-spray inoculation, both in terms of shoot biomass production, and as concentrations of N, P, and $\mathrm{K}$ in leaves. However, under field conditions, some contribution of bacteria reaching the rhizosphere must also take place.

The increased efficiency of nutrient uptake, especially $\mathrm{N}$ and $\mathrm{P}$, are of utmost importance for the sustainability of agricultural systems. According to the planetary boundaries model proposed by Steffen et al. (2015), the biochemical flows of $\mathrm{N}$ and $\mathrm{P}$ have been exploited beyond the zone of uncertainty, and are now at high risk. Any mechanism that increases the use efficiency of these nutrients by crops is particularly relevant.

In our experiments, inoculation with $A$. brasilense significantly increased $\mathrm{N}$ and $\mathrm{K}$ leaf concentrations, whereas inoculation with $P$. fluorescens significantly increased $\mathrm{P}$ and $\mathrm{K}$ leaf concentrations. This might certainly be highly attributed to the improvement in root architecture promoted by both bacteria due to the synthesis of phytohormones, with an emphasis on IAA, improving the ability of plants to explore their environment for water and nutrients. This improved efficiency is ultimately translated into forage biomass production which, in turn, makes possible to increase the support capacity of the pastures to the animals. P. fluorescens CNPSo 2017 may help the $P$ nutrition via solubilization of phosphates and siderophores synthesis. In addition, growth promotion by $P$. fluorescens is also favored by the synthesis of ACC-deaminase, that cleaves the precursor of ethylene in higher plants. Also important, ACC-deaminase in P. fluorescens (Santoyo et al. 2016) and other mechanisms in A. brasilense (Fukami et al. 2017, 2018b) improve tolerance to abiotic and biotic stresses.

Considering the inoculation with and without supplementary dose of $\mathrm{N}$-fertilizer, seed inoculation with A. brasilense or P. fluorescens significantly increased forage production by $16.8 \%$ and $15.2 \%$, respectively, representing an excellent opportunity for areas undergoing pasture renovation. Outstanding results were also observed for leaf-spray inoculation, on average $16.8 \%$ and $14.2 \%$, respectively. In relation to nutrient concentrations, statistically significant enrichment was also achieved. Again, considering the treatments with and without $\mathrm{N}$-fertilizer, the average gains with seed or leafspray inoculation with $A$. brasilense were of $11.7 \%$ and $20.7 \%$ for $\mathrm{N}$ and of $9.9 \%$ and $11.3 \%$ for K, respectively. For inoculation with $P$. fluorescens, the average increases for seed and leaf-spray inoculation were, respectively, $33.3 \%$ and $36.6 \%$ for $\mathrm{P}$, and $10.6 \%$ and $13.6 \%$ for K. Noteworthy, the highest gains for nutrients 
concentration were observed with the supplementary level of $\mathrm{N}$-fertilizer. These results translate not only into more feed, but feed of improved nutritional value for livestock. As in our previous study (Hungria et al. 2016), we also consider important to estimate the contribution of PGPR to the $\mathrm{C}$ sequestration in pastures. Considering the average of all inoculated treatments, via seed or leaf-spray, with and without extra N supply, the average shoot biomass production was $246.25 \mathrm{~g} \mathrm{~m}^{-2}$, whereas the $\mathrm{C}$ and $\mathrm{C}+\mathrm{N}$ controls averaged $212.75 \mathrm{~g} \mathrm{~m}^{-2}$; therefore, the inoculation with PGPR resulted in an average increase of $0.335 \mathrm{Mg} \mathrm{ha}^{-1}$. Considering the average $\mathrm{C}$ content in the Urochloa biomass, $443 \mathrm{~g} \mathrm{~kg}^{-1}$ (Sá et al. 2015), estimates are of $0.147 \mathrm{Mg} \mathrm{ha}^{-1}$ of $\mathrm{C}$ sequestration, or $0.539 \mathrm{Mg} \mathrm{CO}_{2^{-}}$ eq $\mathrm{ha}^{-1}$ with the brachiarias per cut, representing plants growing for an average of three months. With the adoption of PGPR in 20 million ha, this would imply in sequestration of $2.94 \mathrm{Tg}$ of $\mathrm{C}$, or $10.78 \mathrm{Tg} \mathrm{CO}_{2}$-eq per growing cycle. Although these are important estimates, we must consider that the gains in plant biomass are translated in higher stocking rates or animal protein, and the main expected mitigation should rely on the reduction of emission intensity, both due to the reduction in the addition of $\mathrm{N}$-fertilizer and in the lower emission of methane by the cattle, due to the nutrition with forage of better quality. However, it is important to highlight that our results refer to small-scale field trials in comparison to the areas under pastures in Brazil, pointing out the need for future research on multilocational trials on pastures under grazing across different agroecosystems at the country level to validate the proposed technology.

\section{Conclusion}

Our results demonstrate that it is viable to boost plant growth, forage biomass production and plant nutrient status by inoculation with PGPR either of newly implanted pastures of Urochloa or those that have already been implanted. Results of inoculation with A. brasilense and $P$. fluorescens were highly attributed to improvement in root architecture due to the synthesis of phytohormones. In addition, $P$. fluorescens contributes with the synthesis of ACC-deaminase, lowering the ethylene levels in plants and to $\mathrm{P}$ nutrition by the solubilization of phosphates and the synthesis of siderophores, while A. brasilense contributes to the $\mathrm{N}$ nutrition via biological nitrogen fixation. Root growth improvement by both $A$. brasilense and $P$. fluorescens also increased $\mathrm{K}$ uptake. The benefits were confirmed by seed and leaf-spray inoculation and in this last case might be related mainly to systemic signaling from shoots to roots. Taking into account the extension of land occupied with pastures in Brazil (180 Mha), our results demonstrate that a simple biotechnological tool based on PGPB may help to increase the efficiency of forage and animal protein production in the country, thus helping to increase food production with reduced environmental impacts.

Authors' contributions Conceived and designed the experiments: MH, RSA, MAN.

Performed the experiments: MH, ABLR, ALPN, MAN.

Analyzed the data: MH, ABLR, ALPN, MAN.

Contributed reagents/materials/analysis tools: $\mathrm{MH}, \mathrm{RSA}$, MAN.

Wrote the paper: MH, ABLR, RSA, MAN.

All authors read and approved the final manuscript.

Funding This study was funded by Empresa Brasileira de Pesquisa Agropecuária-Embrapa (20.19.02.009.00.04.001); INCT-Plant-Growth Promoting Microorganisms for Agricultural Sustainability and Environmental Responsibility (CNPq 465133/ 2014-2, Fundação Araucária-STI 043/2019, CAPES); and Total Biotecnologia/Biotrop (Project of Technical Collaboration with Embrapa Soja $N^{\circ}$ 20900.09/0080-2). Data availabilityThe datasets generated during and/or analyzed during the current study are available from the corresponding author on reasonable request.

Declarations

Ethics approval Authors declare no conflict of ethics.

Consent to participate All authors declare consent of participation.

Consent for publication All authors declare consent of publication.

Conflicts of interest/competing interests Authors declare no conflict of interest.

Open Access This article is licensed under a Creative Commons Attribution 4.0 International License, which permits use, sharing, adaptation, distribution and reproduction in any medium or format, as long as you give appropriate credit to the original author(s) and the source, provide a link to the Creative Commons licence, and indicate if changes were made. The images or other third party material in this article are included in the article's Creative Commons licence, unless indicated otherwise in a credit line to the material. If material is not included in the article's Creative Commons licence and your intended use is not permitted by statutory regulation or exceeds the permitted use, you will need to obtain permission directly from the copyright holder. To view a copy of this licence, visit http://creativecommons.org/licenses/by/4.0/. 


\section{References}

Aguirre PF, Olivo CJ, Rodrigues PF, Falk DR, Adams CB, Schiafino HP (2018) Forage yield of Coastcross-1 pastures inoculated with Azospirillum brasilense. Acta Sci Anim Sci 40:1-8. https://doi.org/10.4025/actascianimsci.v40i1.36392

Barbieri P, Galli E (1993) Effect on wheat root development of inoculation with an Azospirillum brasilense mutant with altered indole-3-acetic acid production. Res Microbiol 144: 69-75. https://doi.org/10.1016/0923-2508(93)90216-O

Barbosa JZ, Hungria M, Sena JVS, Poggere G, Reis AR, Corrêa RS (2021) Meta-analysis reveals benefits of co-inoculation of soybean with Azospirillum brasilense and Bradyrhizobium spp. in Brazil. Appl Soil Ecol 163:103913. https://doi. org/10.1016/j.apsoil.2021.103913

Bashan Y, de-Bashan LE, Prabhu SR, Hernandez J (2014) Advances in plant growth-promoting bacterial inoculant technology: formulations and practical perspectives (1988 2013). Plant Soil 378:1-33. https://doi.org/10.1007/s11104013-1956-x

Bishnoi U (2015) PGPR interaction: an ecofriendly approach promoting the sustainable agriculture system. Adv Bot Res 75:81-113. https://doi.org/10.1016/bs.abr.2015.09.006

Carmo CAFS, Araujo WS, Bernardi ACC, Saldanha MFC (2000) Métodos de análise de tecidos vegetais utilizados na Embrapa Solos. Circular técnica ${ }^{\circ}$ 6. Embrapa Solos, Rio de Janeiro

Cassán F, Coniglio A, López G, Molina R, Nievas S, Carlan CLN, Donadio F, Torres D, Rosas S, Pedrosa FO, Souza E, DíazZorita M, de-Bashan L, Mora V (2020) Everything you must know about Azospirillum and its impact on agriculture and beyond. Biol Fertil Soils 56:461-479. https://doi.org/10.1007 /s00374-020-01463-y

Chibeba AM, Kyei-Boahen S, Guimarães MF, Nogueira MA, Hungria M (2017) Isolation, characterization and selection of indigenous Bradyrhizobium strains with outstanding symbiotic performance to increase soybean yields inMozambique. Agric Ecosyst Environ 246:291-305. https://doi.org/10.1016/j.agee.2017.06.017

Criollo PJ, Obando M, Sánchez ML, Bonilla R (2012) Efecto de bacterias promotoras de crecimiento vegetal (PGPR) asociadas a Pennisetum clandestinum en el altiplano cundiboyacense. Rev Corpoica Cienc y Tecnol Agropecu 13:189-195. https://doi.org/10.21930/rcta.vol13_num2_ art:254

Dias-Filho MB (2014) Diagnóstico das pastagens no Brasil. Embrapa Amazônia Oriental, Belém

Döbereiner J, Marriel IE, Nery M (1976) Ecological distribution of Spirillum lipoferum Beijerinck. Can J Microbiol 22:14641473. https://doi.org/10.1139/m76-217

Donagema GK, Campos DVB, Calderano SB, Teixeira WG, Viana JHM (2011) Manual de métodos de análise de solos. Documentos 132. Embrapa Solos, Rio de Janeiro

Duarte CFD, Cecato U, Hungria M, Fernandes HJ, Biserra TT, Galbeiro S, Toniato AKB, Silva DR (2020) Morphogenetic and structural characteristics of Urochloa species under inoculation with plant-growth-promoting bacteria and nitrogen fertilisation. Crop Pasture Sci 71:82-89. https://doi. org $/ 10.1071 / \mathrm{CP} 18455$
Duca D, Lorv J, Patten CL, Rose D, Glick BR (2014) Indole-3acetic acid in plant-microbe interactions. Antonie Van Leeuwenhoek 106:85-125. https://doi.org/10.1007/s10482013-0095-y

Embrapa (2018) Agricultura e preservação ambiental: uma análise do cadastro ambiental rural. https://www.embrapa. br/en/car/sintese. Accessed 23 Oct 2020

Embrapa Soja (2020) Tecnologias de produção de soja - região central do Brasil 2020. https://www.infoteca.cnptia.embrapa. br/infoteca/bitstream/doc/1123928/1/SP-17-2020-online.pdf. Accessed 11 Nov 2020

Fukami J, Nogueira MA, Araujo RS, Hungria M (2016) Accessing inoculation methods of maize and wheat with Azospirillum brasilense. AMB Express 6:1-13. https://doi.org/10.1186 /s13568-015-0171-y

Fukami J, Ollero FJ, Megías M, Hungria M (2017) Phytohormones and induction of plant-stress tolerance and defense genes by seed and foliar inoculation with Azospirillum brasilense cells and metabolites promote maize growth. AMB Express 7:153. https://doi.org/10.1186 /s13568-017-0453-7

Fukami J, Abrantes JLF, del Cerro P, Nogueira MA, Ollero FJ, Megías M, Hungria M (2018a) Revealing different strategies of quorum sensing in Azospirillum brasilense strains Ab-V5 and Ab-V6. Arch Microbiol 200:47-56. https://doi. org/10.1007/s00203-017-1422-x

Fukami J, Cerezini P, Hungria M (2018b) Azospirillum: benefits that go far beyond biological nitrogen fixation. AMB Express 8:73. https://doi.org/10.1186/s13568-018-0608-1

Garcia-Montiel DC, Neill C, Melillo J, Thomas S, Steudler PA, Cerri CC (2000) Soil phosphorus transformations following forest clearing for pasture in the Brazilian Amazon. Soil Sci Soc Am J 64:1792-1804. https://doi.org/10.2136 /sssaj2000.6451792x

Goswami D, Thakker JN, Dhandhukia PC (2016) Portraying mechanics of plant growth promoting rhizobacteria (PGPR): a review. Cogent Food Agric 2:1127500. https://doi.org/10.1080/23311932.2015.1127500

Haling RE, Brown LK, Bengough AG, Young IM, Hallett PD, White PJ, George TS (2013) Root hairs improve root penetration, root-soil contact, and phosphorus acquisition in soils of different strength. J Exp Bot 64:3711-3721. https://doi. org/10.1093/jxb/ert200

Haling RE, Yang Z, Shadwell N, Culvenor RA, Stefanski A, Ryan MH, Sandral GA, Kidd DR, Lambers H, Simpson RJ (2016) Root morphological traits that determine phosphorusacquisition efficiency and critical external phosphorus requirement in pasture species. Funct Plant Biol 43:815-826. https://doi.org/10.1071/FP16037

Hoagland DR, Arnon DI (1950) The water culture method for growing plants without soils. California Agricultural Experimental Station, Berkeley

Hodge A (2004) The plastic plant: root responses to heterogeneous supplies of nutrients. New Phytol 162:9-24. https://doi. org/10.1111/j.1469-8137.2004.01015.x

Hungria M, Mendes IC (2015) Nitrogen fixation with soybean: the perfect symbiosis? In: de Bruijn FJ (ed) Biological nitrogen fixation. Wiley \& Sons, Hoboken, pp 1005-1019. https://doi. org/10.1002/9781119053095.ch99

Hungria M, Campo RJ, Souza EM, Pedrosa FO (2010) Inoculation with selected strains of Azospirillum brasilense and 
A. lipoferum improves yields of maize and wheat in Brazil. Plant Soil 331:413-425. https://doi.org/10.1007/s11104009-0262-0

Hungria M, Nogueira MA, Araujo RS (2013) Co-inoculation of soybeans and common beans with rhizobia and azospirilla: strategies to improve sustainability. Biol Fertil Soils 49:791801. https://doi.org/10.1007/s00374-012-0771-5

Hungria M, Nogueira MA, Araujo RS (2016) Inoculation of Brachiaria spp. with the plant growth-promoting bacterium Azospirillum brasilense: an environment-friendly component in the reclamation of degraded pastures in the tropics. Agric Ecosyst Environ 221:125-131. https://doi.org/10.1016/j. agee.2016.01.024

Hungria M, Ribeiro RA, Nogueira MA (2018) Draft genome sequences of Azospirillum brasilense strains $\mathrm{Ab}-\mathrm{V} 5$ and $\mathrm{Ab}-\mathrm{V} 6$, commercially used in inoculants for grasses and 1egumes in Brazil. Genome Announc 6:e00393-e00318. https://doi.org/10.1128/genomeA.00393-18

Jank L, Barrios SC, Valle CB, Simeão RM, Alves GF (2014) The value of improved pastures to Brazilian beef production. Crop Pasture Sci 65:1132-1137. https://doi.org/10.1071 /CP13319

Kewscience (2021) Plants of the World online: Urochloa. http://powo.science.kew.org/?q=urochloa. Accessed 24 Jan 2021

King EO, Ward MK, Raney DE (1954) Two simple media for the demonstration of pyocyanin and fluorescin. J Lab Clin Med 44:301-307

Kochar M, Upadhyay A, Srivastava S (2011) Indole-3-acetic acid biosynthesis in the biocontrol strain Pseudomonas fluorescens Psd and plant growth regelation by hormone overexpression. Res Microbiol 162:426-435. https://doi. org/10.1016/j.resmic.2011.03.006

Leite RC, Santos AC, Santos JGD, Leite RC, Oliveira LBT, Hungria M (2019a) Mitigation of Mombasa grass (Megathyrsus maximus) dependence on nitrogen fertilization as a function of inoculation with Azospirillum brasilense. Rev Bras Cienc Solo 43:e0180234. https://doi.org/10.1590 /18069657rbcs20180234

Leite RC, Santos JGD, Silva EL, Alves CRCR, Hungria M, Leite RC, Santos AC (2019b) Productivity increase, reduction of nitrogen fertiliser use and drought-stress mitigation by inoculation of Marandu grass (Urochloa brizantha) with Azospirillum brasilense. Crop Pasture Sci 70:61-67. https://doi.org/10.1071/CP18105

Lynch JP (2019) Root phenotypes for improved nutrient capture: an underexploited opportunity for global agriculture. New Phytol 223:548-564. https://doi.org/10.1111/nph.15738

Maheshwari DK, Dheeman S, Agarwal M (2015) Phytohormoneproducing PGPR for sustainable agriculture. In: Maheshwari DK (ed) Bacterial metabolites in sustainable agroecosystem. Springer, Cham, pp 159-182

Mannion AM, Morse S (2012) Biotechnology in agriculture: agronomic and environmental considerations and reflections based on 15 years of GM crops. Prog Phys Geogr 36:747763. https://doi.org/10.1177/0309133312457109

MAPA (2011) (Ministério da Agricultura, Pecuária e Abastecimento). INSTRUÇÃO NORMATIVA $\mathrm{N}^{\circ} 13$, de 24 de março de 2011. https://www.gov.br/agricultura/ptbr/assuntos/insumos-agropecuarios/insumos- agricolas/fertilizantes/legislacao/in-sda-13-de-24-03-2011inoculantes.pdf/view. Accessed 13 May 2020

Molina-Favero C, Creus CM, Simontacchi M, Puntarulo S, Lamattina L (2008) Aerobic nitric oxide production by Azospirillum brasilense Sp245 and its influence on root architecture in tomato. Mol Plant-Microbe Interact 21: 1001-1009. https://doi.org/10.1094/MPMI-21-7-1001

Monk J, Gerard E, Young S, Widdup K, O'Callaghan M (2009) Isolation and identification of plant growth-promoting bacteria associated with tall fescue. Proc N Z Grassland Assoc 71: 211-216. https://doi.org/10.33584/jnzg.2009.71.2751

Moore KJ, Moser LE, Vogel KP, Waller SS, Johnson BE, Pedersen JF (1991) Describing and quantifying growth stages of perennial forage grasses. Agron J 83:1073-1077. https://doi.org/10.1177/0309133312457109

Oliveira OC, Oliveira IP, Alves BJR, Urquiaga S, Boddey RM (2004) Chemical and biological indicators of decline/ degradation of Brachiaria pastures in the Brazilian Cerrado. Agric Ecosyst Environ 103:289-300. https://doi.org/10.1016 /j.agee.2003.12.004

Ortiz-Castro R, Campos-García J, López-Bucio J (2020) Pseudomonas putida and Pseudomonas fluorescens influence Arabidopsis root system architecture through na auxin response mediated by bioactive cyclodipeptides. J Plant Growth Regul 39:254-265. https://doi.org/10.1007/s00344019-09979-w

Pallai R, Hynes RK, Verma B, Nelson LM (2012) Phytohormone production and colonization of canola (Brassica napus L.) roots by Pseudomonas fluorescens 6-8 under gnotobiotic conditions. Can J Microbiol 58:170-178. https://doi. org/10.1139/w11-120

Pedreira BC, Barbosa PL, Pereira LET, Mombach MA, Domiciano LF, Pereira DH, Ferreira A (2017) Tiller density and tillering on Brachiaria brizantha cv. Marandu pastures inoculated with Azospirillum brasilense. Arq Bras Med Vet Zootec 69:1039-1046. https://doi.org/10.1590/1678-41629034

Puente ML, Gualpa JL, Lopez GA, Molina RM, Carletti SM, Cassán FD (2018) The benefits of foliar inoculation with Azospirillum brasilense in soybean are explained by an auxin signaling model. Symbiosis 76:41-49. https://doi. org/10.1007/s13199-017-0536-x

Puente ML, Zawoznik M, Sabando ML, Perez G, Gualpa JL, Carletti SM, Cassán FD (2019) Improvement of soybean grain nutritional quality under foliar inoculation with Azospirillum brasilense strain Az39. Symbiosis 77:41-47. https://doi.org/10.1007/s13199-018-0568-x

Rondina ABL, Sanzovo AWS, Guimarães GS, Wendling JR, Nogueira MA, Hungria M (2020) Changes in root morphological traits in soybean co-inoculated with Bradyrhizobium spp. and Azospirillum brasilense or treated with A. brasilense exudates. Biol Fertil Soils 56:537-549. https://doi. org/10.1007/s00374-020-01453-0

Sá JCM, Séguy L, Tivet F, Lal R, Bouzinac S, Borszowskei PR, Briedis C, Santos JB, Hartman DC, Bertoloni CG, Rosa J, Friedrich T (2015) Carbon depletion by plowing and its restoration by no-till cropping systems in Oxisols of subtropical and tropical agro-ecoregions in Brazil. Land Degrad Dev 26:531-543. https://doi.org/10.1002/ldr.2218

Sá GCR, Carvalho CLM, Moreira A, Hungria M, Nogueira MA, Heinrichs R, Soares Filho CV (2019a) Biomass yield, 
nitrogen accumulation and nutritive value of Mavuno grass inoculated with plant-growth-promoting bacteria. Commun Soil Sci Plant Anal 50:1931-1942. https://doi.org/10.1080 /00103624.2019.1648498

Sá GCR, Hungria M, Carvalho CLM, Moreira A, Nogueira MA, Heinrichs R, Soares Filho CV (2019b) Nutrients uptake in shoots and biomass yields and roots and nutritive values of Zuri Guinea grass inoculated with plant growth-promoting bacteria. Commun Soil Sci Plant Anal 50:2927-2940. https://doi.org/10.1080/00103624.2019.1689256

Sandini IE, Pacentchuk F, Hungria M, Nogueira MA, Cruz SP, Nakatani AS, Araujo RS (2019) Seed inoculation with Pseudomonas fluorescens promotes growth, yield and reduces nitrogen application in maize. Int J Agric Biol 22: 1369-1375. https://doi.org/10.17957/IJAB/15.1210

Santos EDG, Paulino MF, Queiroz DS, Fonseca DM, Valadares Filho SC, Lana RP (2004) Avaliação de pastagem diferida de Brachiaria decumbens Stapf. 2. Disponibilidade de forragem e desempenho animal durante a seca. Rev Bras Zootec 33: 214-224. https://doi.org/10.1590/S 1516 35982004000100025

Santos MS, Nogueira MA, Hungria M (2019) Microbial inoculants: reviewing the past, discussing the present and previewing an outstanding future for the use of beneficial bacteria in agriculture. AMB Express 9:205. https://doi. org/10.1186/s13568-019-0932-0

Santos MS, Rodrigues TF, Ferreira E, Megías M, Nogueira MA, Hungria M (2020) Method for recovering and counting viable cells from maize seeds inoculated with Azospirillum brasilense. J Pure Appl Microbiol 14:195-204. https://doi. org/10.22207/JPAM.14.1.21

Santos MS, Nogueira MA, Hungria M (2021) Outstanding impact of Azospirillum brasilense strains Ab-V5 and Ab-V6 on the Brazilian agriculture: lessons that farmers are receptive to adopt new microbial inoculants. Rev Bras Cienc Solo 45: e0200128. https://doi.org/10.36783/18069657rbcs20200128

Santoyo G, Moreno-Hagelsieb G, Orozco-Mosqueda M d C, Glick BR (2016) Plant growth-promoting bacterial endophytes. Microbiol Res 183:92-99. https://doi.org/10.1016/j. micres.2015.11.008

Soil Survey Staff (2014) Keys to soil taxonomy, 12th edn. USDA, Washington

Souza R, Ambrosini A, Passaglia LMP (2015) Plant growth promoting bacteria inoculants in agricultural soils. Genet Mol Biol 38:401-419. https://doi.org/10.1590/S1415475738420150053

Steffen W, Richardson K, Rockström J, Cornell SE, Fetzer I, Bennett EM, Biggs R, Carpenter SR, de Vries W, de Wit
CA, Folke C, Gerten D, Heinke J, Mace GM, Persson LM, Ramanathan V, Reyers B, Sörlin S (2015) Planetary boundaries: guiding human development on a changing planet. Science 347:1259855. https://doi.org/10.1126 /science. 1259855

Tennant D (1975) A test of modified line intersect method of estimating root length. J Ecol 63:995-1001. https://doi. org/10.2307/2258617

United Nations (2019) World population prospects 2019. https://population.un.org/wpp/ Accessed 20 Oct 2020

USDA (2020) Livestock and poultry: world markets and trade, October 2020 . https://apps.fas.usda. gov/psdonline/circulars/livestock_poultry.pdf Accessed 20 Oct 2020

White PJ (2019) Root traits benefitting crop production in environments with limited water and nutrient availability. Ann Bot 124:883-890. https://doi.org/10.1093/aob/mcz162

Yates RJ, Howieson JG, Hungria M, Bala A, O’Hara GW, Terpolilli J (2016) Authentication of rhizobia and assessment of the legume symbiosis in controlled plant growth systems. In: Howieson JG, Dilworth MJ (eds) Working with rhizobia. ACIAR, Canberra, pp 73-108

York LM, Nord EA, Lynch JP (2013) Integration of root phenes for soil resource acquisition. Front Plant Sci 4:355. https://doi.org/10.3389/fpls.2013.00355

Zangaro W, Nishidate FR, Camargo FRS, Romagnoli GG, Vandresen J (2005) Relationships among arbuscular mycorrhizas, root morphology and seedling growth of tropical native woody species in southern Brazil. J Trop Ecol 21: 529-540. https://doi.org/10.1017/S0266467405002555

Zhao L, Lu L, Wang A, Zhang H, Huang M, Wu H, Xing B, Wang Z, Ji R (2020) Nano-biotechnology in agriculture: use of nanomaterials to promote plant growth and stress tolerance. J Agric Food Chem 68:1935-1947. https://doi.org/10.1021 /acs.jafc.9b06615

Zimmer AH, Macedo MCM, Kichel AN, Almeida RG (2012) Degradação, recuperação e renovação de pastagens. Embrapa Gado de Corte, Campo Grande

Pre-submission review The manuscript was internally reviewed (in Portuguese) by the Internal Technical Committee of Embrapa Soja Center (CTI, cnpso.cti@embrapa.br; Executive Chief of CTI - Dr. Adilson de Oliveira Junior - adilson.oliveira@embrapa.br).

Publisher's note Springer Nature remains neutral with regard to jurisdictional claims in published maps and institutional affiliations. 